Volume III, No.1 Juni 2013/1434 H

\title{
ANALISIS FAKTOR-FAKTOR YANG MEMPENGARUHI PERMINTAAN PEMBIAYAAN MUDHARABAH PADA BMT HIDAYAH UMAT YOGYAKARTA 2013
}

\author{
Murningsih dan Ahmad Yunadi \\ (Prodi Ekonomi Syariah Sekolah Tinggi Ilmu Agama Alma Ata)
}

\begin{abstract}
Murningsih. 2009. "Analysis of Factors Affect the Demand of Financing Mudharabah at BMT Hidayah Umat Yogyakarta in 2013". A Thesis. Yogyakarta: School of Theology Alma Ata.

KJKS BMT is an institution that serves as a financial intermediary institution. KJKS BMT distributes third party funds to the people. Among of them are mudharabah and musyarakah financing. The background of this research is that sharia, service, product, and promotion are the factors to be considered by the people to apply for funding to BMT Hidayah Ummat. This study was conducted to determine the influence of sharia, services, products, and promotions on the demand of financing mudharabah at BMT Hidayah Ummah.

Type of research is a field research with documentation of data collecting methods, because the data in this study is a secondary data. Where as this data obtained from customers data is filled directly. Analysis tool of this research is multiple linear regression tests that use the classicallinear regression tests and statistical tests.

The resultof t-test analysis shows that each of the independent variables significantly affects the demand of financing in BMT Hidayah Umat Yogyakarta. In the F test shows that the sharia independent variables influences significantly, while theservice, product, and promotionare not influencing significantly for the demand of financing mudharabah. The determinants coefficient $\left(\mathrm{R}^{2}\right)$ of 0.729 , which means that the demand for financing mudharabah in BMT Hidayah Umat can be explained by the independent variables was $72.9 \%$. The remaining of $27.1 \%$ is influenced by other variables out side this research.

Keyword: Financing Mudharabah, BMT.

\section{A. Pendahuluan}

Perkembangan perbankan syariah dewasa ini di Indonesia bukan merupakan gejala baru dalam dunia bisnis syariah. Keadaan ini ditandai dengan semangat tinggi dari berbagai kalangan ulama, akademisi dan
\end{abstract}


praktisi untuk mengembangkan perbankan sekitar pertengahan abad 20 . Bank syariah adalah bank yang beroperasi dengan tidak mengandalkan pada bunga. Bank syariah atau biasa disebut dengan bank tanpa bunga adalah lembaga keuangan atau perbankan yang operasional dan produknya dikembangkan berlandaskan pada al-Qur'an dan al-hadits. Dengan kata lain, bank syariah adalah lembaga keuangan yang usaha pokoknya memberikan pembiayaan dan jasa-jasa lainnya dengan prinsip syariah Islam. Hal ini berarti dalam operasionalnya mengikuti tata cara berusaha maupun perjanjian berdasarkan Al-Qur'an dan As-Sunnah.

Laporan perkembangan perbankan syariah tingginya pertumbuhan asset tidak terlepas dari tingginya pertumbuhan dana pihak ketiga pada sisi pasiva dan pertumbuhan penyaluran dana pada sisi aktiva. Penghimpunan dana pihak ketiga meningkat 52,79\% dan penyaluran dana masyarakat meningkat sebesar $46,43 \%$. Adapun penghimpunan dana masyarakat terbesar adalah dalam bentuk deposito yaitu $\operatorname{Rp} 62,02$ triliun $(61,06 \%)$ diikuti oleh Tabungan sebesar Rp27,81 triliun (27,38\%) dan Giro sebesar Rp11,05 triliun (10,88\%). Sedangkan perkembangan jumlah Bank Umum Syariah (B\US) dan Unit Usaha Syariah (UUS) sampai dengan tahun 2011 tidak mengalami perubahan, namun demikian jumlah jaringan kantor meningkat. Secara keseluruhan jumlah kantor perbankan syariah meningkat dari 1.477 kantor (2010) menjadi 1.688 kantor, sementara pada tahun 2010 jumlah layanan syariah (office channeling) tetap yaitu 1.277 kantor.

Meningkatnya perkembangan usaha kecil dan menengah, menyebabkan semakin meningkatnya taraf kemakmuran perekonomian masyarakat. Namun, perkembangan usaha kecil dan menengah tersebut tidak disertai dengan tingkat modal yang mencukupi, sehingga bmt menawarkan kebijakan kepada pelaku usaha kecil dan menengah dengan dua jenis pembiayaan yaitu jenis pembiayaan musyarakah dan pembiayaan mudharabah.

Pembiayaan mudharabah merupakan kerjasama antara pihak bank dengan nasabah, dimana dana $100 \%$ dari pihak bank dan keuntungan dibagi menurut akad/perjanjian. Dengan kata lain modal disediakan oleh pihak bank sedangkan nasabah menjalankan usahanya. Pembiayaan mudharabah dapat dilakukan untuk membiayai suatu proyek bersama antara nasabah dengan bank. Nasabah debitur dapat mengajukan proposal kepada bank syariah untuk mendanai suatu proyek tertentu atau usaha tertentu dan kemudian akan disepakati berapa modal dari bank dan berapa modal dari nasabah kreditur serta akan ditentukan bagi hasilnya bagi masing-masing pihak berdasarkan persentase pendapatan atau keuntungan bersih dari proyek atau usaha tersebut sesuai kesepakatan.

Prinsip bagi hasil (mudharabah) merupakan suatu ketentuan dalam suatu pembiayaan yang telah disepakati bersama antara bank (shahibul maal) dengan pihak pengelola dana (mudharib) yang berdasar syariah. Jika terjadi kerugian dalam usaha, maka hal tersebut sebagai reduksi atas modal dan ditanggung oleh pemilik modal itu sendiri. Berbeda dengan musyarokah, keuntungan dan kerugian akan dibagi diantara kedua pihak sesuai dengan proporsi pada modal yang diinvestasikan. Salah satu yang menjadi alasan mengapa semakin banyak masyarakat yang memakai

Murningsih 
produk BMT adalah menghindari sistem bunga yang diharamkan karena mengandung unsur riba. sebagaimana larangan dalam Q.S. Al-imran (2): 130. Yang berbunyi:

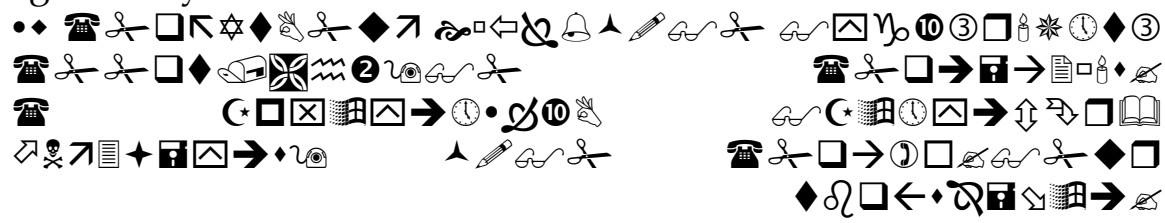

"Hai orang-orang yang beriman, janganlah kamu memakan riba dengan berlipat ganda dan bertakwalah kamu kepada Allah supaya kamu mendapat keberuntungan".

Bait Māal wa Tamwil (BMT) merupakan lembaga keuangan non bank yang operasionalnya sesuai dengan syariat Islam, tidak menggunakkan sistem bunga (riba) melainkan dengan sistem bagi hasil. Bagi hasil inilah yang membedakan antara lembaga keuangan Islam dan non Islam. Jenis kegiatan BMT yaitu mengumpulkan dana dari berbagai sumber seperti zakat, infaq, sadakah dan lain-lain yang dapat dibagikan atau disalurkan kepada yang berhak dalam mengatasi kemiskinan dan kegiatan produktif dalam rangka menciptakan nilai tambah baru dan mendorong pertumbuhan ekonomi yang bersumber daya manusia.

BMT Hidayah Umat Yogyakarta merupakan sebuah perusahaan jasa keuangan yang sedang berkembang. Dan dilihat dari segi permasalahan yang ada, bahwa minat nasabah dalam pembiayaan mudharabah sangat sedikit, sehingga memerlukan langkah-langkah guna meningkatkan kepuasan nasabahnya. Oleh karena itu, penulis memilih BMT Hidayah Umat Yogyakarta sebagai tempat penelitian, dengan harapan mampu memberikan manfaat bagi kemajuan BMT Hidayah Umat Yogyakarta.

\section{B. Rumusan Masalah}

Berdasarkan uraian pada latar belakang masalah tersebut di atas, maka dapat dirumuskan permasalahan sebagai berikut:"Apakah faktor syariah, pelayanan, produk, dan promosi mempengaruhi permintaan pembiayaan mudharabah pada BMT Hidayah Umat Yogyakarta?"

\section{Tujuan Penelitian}

Berdasarkan perumusan permasalahan di atas, maka tujuan penelitian ini yang hendak dicapai dalam penelitian ini adalah:

1. Menganalisis faktor-faktor yang mempengaruhi permintaan pembiayaan mudharabah pada BMT Hidayah Umat Yogyakarta.

Analisis

2. Mengidentifikasi dan menganalisis karakteristik responden dalam pembiayaan mudharabah pada BMT Hidayah Umat Yogyakarta.

Faktor

D. Landasan Teori

1. Kegiatan Bank Syariah Dalam Prinsip Islam

a) Aqidah :

Komponen ajaran Islam yang mengatur tentang keyakinan atas keberadaan dan kekuasaan Allah, sehingga harus menjadi keimanan seorang muslim manakala melakukan berbagai 
aktivitas di muka bumi semata-mata untuk mendapatkan keridhaan Allah dan sebagai khalifah yang mendapat amanah dari Allah.

b) Syariah :

Komponen ajaran Islam yang mengatur tentang kehidupan seorang muslim, baik dalam bidang ibadah maupun dalam bidang muamalah yang merupakan aktualisasi dari aqidah yang menjadi keyakinannya. Muamalah meliputi berbagai bidang kehidupan, antara lain yang menyangkut ekonomi atau harta dan perniagaan disebut muamalah maliyah.

c) Akhlaq :

Landasan perilaku dan kepribadian yang akan mencirikan dirinya sebagai seorang muslim yang taat berdasarkan syariah dan aqidah yang menjadi pedoman hidupnya, sehingga memiliki akhlaqul karimah sebagaimana hadits nabi menyatakan "Tidaklah sekiranya Aku diutus untuk menjadikan akhlaqul karimah".

2. Pengertian Pemasaran Bank

Pemasaran Bank adalah suatu proses untuk mendapatkan dan mempertukarkan produk atau jasa bank yang ditujukan untuk memenuhi kebutuhan dan keinginan nasabah dengan cara memberikan kepuasan.

Dari definisi ini beberapa pengertian yang perlu diketahui adalah sebagai berikut:

a) Permintaan adalah suatu keinginan manusia yang didukung oleh daya belinya. Artinya, permintaan akan terjadi apabila konsumen memiliki sejumlah dana atau barang pengganti untuk memperoleh barang yang lain. Pertukaran adalah tindakan untuk memperoleh suatu barang yang diinginkan dari seseorang dengan menawarkan sesuatu sebagai penggantinya.

b) Pasar adalah himpunan nasabah (pembeli nyata dan pembeli potensial) atas suatu produk, baik barang maupun jasa. Pasar dapat diartikan pula sebagai tempat penjual dan pembeli melakukan transaksi.

c) Kebutuhan nasabah bank adalah suatu keadaan yang dirasakan tidak ada dalam diri seseorang.

d) Keinginan nasabah bank adalah merupakan kebutuhan yang dibentuk oleh kultur dan kepribadian individu.

3. Bauran Pemasaran

Artinya bauran pemasaran adalah seperangkat alat yang digunakan perusahaan untuk terus menerus mencapai tujuan pemasarannya di pasar sasaran.

Berikut ini elemen marketing mix menurut fandy tjiptono yaitu:

a) Harga (Price)

artinya harga adalah sejumlah uang yang dikeluarkan oleh suatu produk/jasa atau sejumlah nilai yang konsumen tukarkan untuk memperoleh manfaat dari penggunaan produk.

b) Promosi (Promotion) 
Merupakan salah satu bauran pemasaran yang mutlak digunakan dalam usaha perusahaan untuk lebih memperkenalkan suatu produk, menarik minat serta mempengaruhi prilaku konsumen untuk berkonsumsi. promosi tidak terlepas dari bauran promosi yang merupakan suatu kombinasi beberapa unsur seperti periklanan (advertising), penjualan perorangan (personal selling), promosi penjualan (sales promotion) dan publisitas.

c) Produk ( Product)

adalah segala sesuatu yang dapat ditawarkan ke pasar untuk memuaskan kebutuhan atau keinginan.

Merupakan elemen bauran pemasaran yang paling mendasar, yaitu kombinasi barang dan jasa yang di tawarkan oleh perusahaan kepada sasaran untuk dapat di konsumsi, dan memenuhi kebutuhan atau keinginan konsumen.

d) pelayanan (customer)

adalah pada pemasaran jasa lebih dilihat sebagai outcome dari kegiatan distribusi dan strategi, dimana pelayanan diberikan kepada konsumen untuk mencapai kepuasan.

4. Pembiayaan

Pembiayaan secara luas berarti financing, atau pembelanjaan, yaitu pendanaan yang dikeluarkan untuk mendukung investasi yang telah direncanakan, baik dilakukan sendiri maupun dijalankan oleh orang lain. Seperti yang diungkapkan dalam alQur'an surat An-Nisa': 29

Analisis

Faktor

113

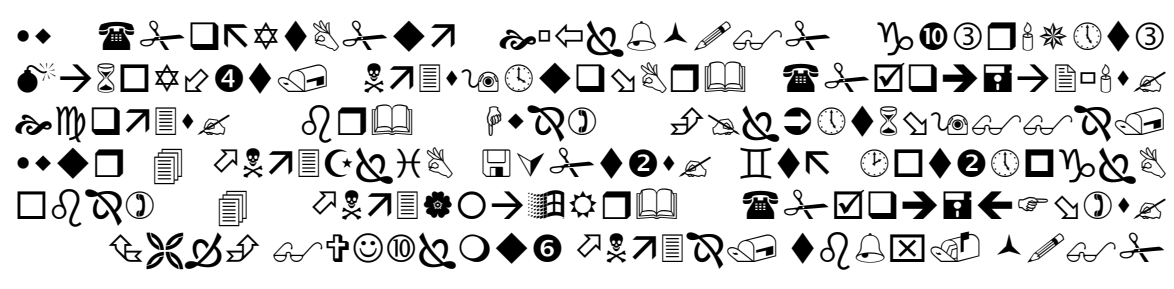

"Hai orang-orang yang beriman, janganlah kamu saling memakan harta sesamamu dengan jalan yang batil, kecuali dengan jalan perniagaan yang Berlaku dengan suka sama-suka di antara kamu. dan janganlah kamu membunuh dirimu; Sesungguhnya Allah adalah Maha Penyayang kepadamu"

5. Mudharabah

Mudharabah berasal dari kata dharb, berarti memukul atau berjalan ini lebih tepetnya adalah proses seseorang memukulkan kakinya dalam menjalankan usaha. Mudharabah yaitu akad kerjasama usaha antara dua pihak, dimana pihak pertama (shahibul maal) menyediakan dana, dan pihak kedua (mudharib) bertanggung jawab atas pengelolaan usaha. Keuntungan usaha secara mudharabah dibagi menurut kesepakatan yang dituangkan dalam kontrak, sedangkan apabila rugi ditanggung oleh pemilik modal selama kerugian itu bukan akibat kelalaian si pengelola, si pengelola harus bertanggung jawab atas kerugian tersebut. Allah SWT berfirman: 


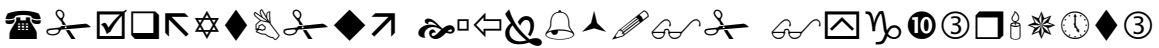

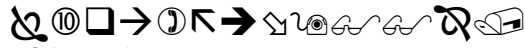

$\rightarrow$ 口内: (10) 8 \&

6口古凹十(3) 2

7)

$\cdot 0$ (ग)

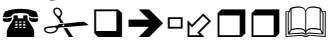

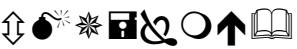

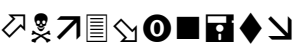

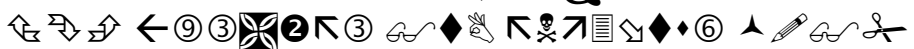

"Hai orang-orang yang beriman, penuhilah aqad-aqad itu. Dihalalkan bagimu binatang ternak, kecuali yang akan dibacakan kepadamu. (yang demikian itu) dengan tidak menghalalkan berburu ketika kamu sedang mengerjakan haji. Sesungguhnya Allah menetapkan hukum-hukum menurut yang dikehendaki-Nya".

6. Baitul Maal wa Tamwil (BMT)

Baitul Maal wa Tamwil (BMT) jika didefinisikan secara harfiah terdiri dari dua kata, yaitu baitul maal yang berarti rumah dana, dan baitul tamwil yang berarti rumah usaha. Sehingga secara keseluruhan pengertian BMT berarti organisasi bisnis yang juga berperan sosial. Landasan hukum yang digunakan dalam menjalankan sistem kinerjanya adalah landasan hukum perkoperasia yaitu Undang-undang no 25 tahun 1992.

\section{E. Metode penelitian}

Penelitian ini dirancang dengan menggunakan pendekatan crosssectional. Subjek dalam penelitian ini ialah nasabah yang telah tercatat aktif sebagai anggota di BMT Hidayah Umat Yogyakarta, sampel yang digunakan 30 atau $10-15 \%$ dari 105 anggota nasabah yang aktif, variabel penelitian yang digunakan adalah variabel bebas dan variabel terikat. Teknik pengambilan data menggunakan observasi, kuesioner dan referensi lain.

\section{Pengolahan dan Analisis Data}

1. Validitas adalah suatu ukuran yang menunjukkan tingkat-tingkat kevalidan atau kesahihan suatu instrument. Suatu instrument yang valid atau sahih mempunyai validitas tinggi.

Rumus yang digunakan untuk uji validitas adalah dengan kolerasi Product Moment yang dikemukakan oleh Arikunto (2002):

Rumus Product Moment

\[ r_{x y}=\frac{\mathrm{N} \sum \mathrm{XY}-\sum \mathrm{X} \sum \mathrm{Y}}{\mathrm{N} \sum \mathrm{x}^{2}-\sum \mathrm{y}^{2} \mathrm{~N} \sum \mathrm{y}^{2}-\sum \mathrm{y}^{2}} \]
Keterangan :
$r_{x y}:$ Koefesiensi kolerasi
$X:$ Skor rata-rata dari $\mathrm{X}$
$Y$ : Skor rata-rata dari $\mathrm{Y}$
$N$ : Jumlah subyek

2. Reliabel artinya dapat dipercaya untuk digunakan sebagai alat pengumpul data karena instrument tersebut sudah baik. Uji reliabilitas dalam penelitian ini adalah menggunakan Cronbach alpha yang berguna untuk mengetahui apakah alat ukur yang dipakai reliabel (handal). 
Rumus Cronbach alpha

$$
r 11=\frac{k}{k-1} \quad \frac{1-\sum \sigma b^{2}}{\sigma^{2} t}
$$

Keterangan:

$\mathrm{R} \quad=$ Reabilitas Instrument

$\mathrm{K}$ = Banyaknya butir pertanyaan atau banyaknya soal.

$\sum \sigma b^{2}=$ Jumlah farians butir

$\mathrm{\sigma}^{2} \mathrm{t} \quad=$ Varians total

jika nilai $\mathrm{r}$ hitung $>\mathrm{r}$ tabel maka item dapat dikatakan reliabel.

$r$ hitung $<\mathrm{r}$ tabel maka item dapat dikatakan tidak reliabel.

3. Regresi linier berganda

Adalah suatu analisis yang digunakan untuk mengetahui bagaimana pengaruh dua variabel-variabel $X$ terhadap satu variabel dependen $Y$, yang dinyatakan dengan persamaan:

Rumus regresi berganda:

$$
\begin{aligned}
& \text { Keterangan: } \\
& \mathrm{Y}=\text { Keputusan Nasabah Menggunakan jasa BMT } \\
& \mathrm{X}_{1} \quad=\text { Faktor Syariah } \\
& \mathrm{X}_{2}=\text { Faktor Pelayanan } \\
& \mathrm{X}_{3} \quad=\text { Faktor Produk } \\
& \text { X4 = Faktor Promosi } \\
& \text { a } \quad=\text { Nilai Konstanta } \\
& \text { b = Koefesien Regresi }
\end{aligned}
$$

4. uji hipotesis

menggunakan (uji parsial/uji-t, uji serentak/uji-f, identifikasi determinan/ $\mathrm{R}^{2}$ ), dan uji asumsi klasik (Uji Normalitas, Heteroskedastisitas, Autokorelasi, dan Multikolinearitas).

\section{F. Hasil Analisis dan Pembahasan}

1. Uji Validitas

Hasil corrected item-total correlation menunjukkan kolerasi antara skor item dengan skor total item yang dapat digunakan untuk menguji validitas instrument pada signifikan 5\%, rtabel sebesar 0,361. Nilai corrected item-total correlation (rhitung) semuanya lebih besar dari nilai rtabel sehingga dapat disimpulkan bahwa ke-20 pernyataan tersebut valid.

2. Uji Reliabilitas

Analisis

Faktor

Tabel reliabilitas

\begin{tabular}{|c|c|}
\hline ralpha & rtabel \\
\hline 0,926 & 0,361 \\
\hline
\end{tabular}

Pada 20 butir pernyataan yang diberikan dengan tingkat signifikan $5 \%$ dan ralpha $=0,926$. ini berarti ralpha $>$ rtabel yaitu 0,361. Sehingga dapat dinyatakan bahwa kuesioner tersebut telah reliabel dan dapat 
disebarluaskan kepada responden sebagai instrument dalam penelitian ini.

3. Analisis Deskriptif Responden

Hasil dari deskrpitif responden memaparkan bahwa jumlah responden berdasarkan umur 26-40 tahun sebesar (43,3\%), responden berdasarkan jenis kelamin $(63,3 \%)$ laki-laki, responden berdasarkan agama $(100 \%)$ islam, berdasarkan pendidikan (40,0\%) SMA, berdasarkan pekerjaan $(43,3 \%)$ swasta, dan berdasarkan penghasilan $\geq \operatorname{Rp} 500.000$ (63,4\%).

4. Deskriptif Variabel

Presentase hasil penelitian setiap variabel customer focus dengan masingmasing tanggapan responden.

a. Pada faktor syariah (X1) mendapatkan respon sebgai berikut:

1) Dari pernyataan sistem bagi hasil yang dirasa lebih adil dibanding sistem bunga (riba), tidak ada responden $(0 \%)$ yang menyatakan sangat tidak setuju, 3 responden $(10,0 \%)$ menyatakan tidak setuju, 5 responden $(16,7 \%)$ menyatakan ragu-ragu, 12 responden $(40,0 \%)$ menyatakan setuju, dan 10 responden $(33,3 \%)$ menyatakan sangat setuju.

2) Dari pernyataan sesuai syariah islam, tidak ada responden $(0 \%)$ yang menyatakan sangat tidak setuju, 3 responden $(10,0 \%)$ menyatakan tidak setuju, 7 responden $(23,3 \%)$ menyatakan ragu-ragu, 15 responden $(50,0 \%)$ menyatakan setuju, dan 5 responden $(16,7 \%)$ menyatakan sangat setuju.

3) Dari pernyataan turut mendorong kemajuan perekonomian secara islami, tidak ada responden $(0 \%)$ yang menyatakan sangat tidak setuju, 3 responden $(10,0 \%)$ menyatakan tidak setuju, 9 responden $(30,0 \%)$ menyatakan ragu-ragu, 10 responden $(33,3 \%)$ menyatakan setuju, dan 8 responden $(26,7 \%)$ menyatakan sangat setuju.

4) Dari pernyataan melaksanakan syariah secara benar, tidak ada responden $(0 \%)$ yang menyatakan sangat tidak setuju, 4 responden $(13,3 \%)$ menyatakan tidak setuju, 6 responden $(20,0 \%)$ menyatakan ragu-ragu, 11 responden $(36,7 \%)$ menyatakan setuju, dan 9 responden $(30,0 \%)$ menyatakan sangat setuju.

b. Pada faktor pelayanan (X2) mendapatkan respon sebgai berikut:

1) Dari pernyataan pelayanan yang cepat terhadap nasabah, tidak ada responden $(0 \%)$ yang menyatakan sangat tidak setuju, 7 responden $(23,3 \%)$ menyatakan tidak setuju, 6 responden $(20,0 \%)$ menyatakan ragu-ragu, 8 responden $(26,7 \%)$ menyatakan setuju, dan 9 responden $(30,0 \%)$ menyatakan sangat setuju.

2) Dari pernyataan pelayanan secara ramah yang diberikan karyawan/i, tidak ada responden $(0 \%)$ yang menyatakan sangat tidak setuju, 8 responden $(26,7 \%)$ menyatakan tidak setuju, 5 responden $(16,7 \%)$ menyatakan ragu-ragu, 12 responden $(40,0 \%)$ menyatakan setuju, dan 5 responden $(16,7 \%)$ menyatakan sangat setuju.

Murningsih

3) Dari pernyataan kesesuaian kesepakatan pada saat akad, tidak ada responden $(0 \%)$ yang menyatakan sangat tidak setuju, 5 
responden $(16,7 \%)$ menyatakan tidak setuju, 6 responden $(20,0 \%)$ menyatakan ragu-ragu, 10 responden (33,3\%) menyatakan setuju, dan 9 responden $(30,0 \%)$ menyatakan sangat setuju.

4) Dari pernyataan kenyamanan para nasabah yang mengajukan pembiayaan, tidak ada responden $(0 \%)$ yang menyatakan sangat tidak setuju, 6 responden $(20,0 \%)$ menyatakan tidak setuju, 7 responden $(23,7 \%)$ menyatakan ragu-ragu, 11 responden $(36,7 \%)$ menyatakan setuju, dan 6 responden $(20,0 \%)$ menyatakan sangat setuju.

c. Pada faktor produk (X3) mendapatkan respon sebgai berikut:

1) Dari pernyataan produk yang beragam dan inovatif, tidak ada responden $(0 \%)$ yang menyatakan sangat tidak setuju, 3 responden $(10,0 \%)$ menyatakan tidak setuju, 9 responden $(30,0 \%)$ menyatakan ragu-ragu, 12 responden $(40,0 \%)$ menyatakan setuju, dan 6 responden $(20,0 \%)$ menyatakan sangat setuju.

2) Dari pernyataan kemudahan bagi nasabah dalam melakukan transaksi pembiayaan secara syariah, tidak ada responden $(0 \%)$ yang menyatakan sangat tidak setuju, 4 responden $(13,3 \%)$ menyatakan tidak setuju, 5 responden $(16,7 \%)$ menyatakan raguragu, 12 responden $(40,0 \%)$ menyatakan setuju, dan 9 responden $(30,0 \%)$ menyatakan sangat setuju.

3) Dari pernyataan presentasi nisbah bagi hasil yang diberikan lebih tinggi dibandingkan dengan BMT lainnya, tidak ada responden $(0 \%)$ yang menyatakan sangat tidak setuju, 2 responden $(6,7 \%)$ menyatakan tidak setuju, 8 responden $(26,6 \%)$ menyatakan ragu-ragu, 14 responden $(46,7 \%)$ menyatakan setuju, dan 6 responden $(20,0 \%)$ menyatakan sangat setuju.

4) Dari pernyataan dalam pembiayaan mudharabah $100 \%$ modal yang diberikan ke pemodal, tidak ada responden $(0 \%)$ yang menyatakan sangat tidak setuju, 5 responden $(16,7 \%)$ menyatakan tidak setuju, 6 responden $(20,0 \%)$ menyatakan raguragu, 8 responden $(26,6 \%)$ menyatakan setuju, dan 11 responden $(36,7 \%)$ menyatakan sangat setuju.

d. Pada faktor promosi (X4) mendapatkan respon sebgai berikut:

1) Dari pernyataan promosi produk melalui penyebaran brosur, tidak ada responden $(0 \%)$ yang menyatakan sangat tidak setuju, 3 responden $(10,0 \%)$ menyatakan tidak setuju, 8 responden $(26,7 \%)$ menyatakan ragu-ragu, 13 responden (43,3\%) menyatakan setuju, dan 6 responden $(20,0 \%)$ menyatakan sangat setuju.

Analisis

2) Dari pernyataan adanya dorongan dari pihak lain ( keluarga, teman, dan lainnya), tidak ada responden $(0 \%)$ yang menyatakan sangat tidak setuju, 5 responden $(16,7 \%)$ menyatakan tidak setuju, 5 responden $(16,7 \%)$ menyatakan ragu-ragu, 12 responden $(40,0 \%)$ menyatakan setuju, dan 8 responden $(26,6 \%)$ menyatakan sangat setuju.

3) Dari pernyataan BMT melakukan promosi melalui periklanan secara menarik, tidak ada responden $(0 \%)$ yang menyatakan sangat tidak setuju, 4 responden $(13,3 \%)$ menyatakan tidak 
setuju, 8 responden $(26,6 \%)$ menyatakan ragu-ragu, 11 responden $(36,7 \%)$ menyatakan setuju, dan 7 responden $(23,3 \%)$ menyatakan sangat setuju.

4) Dari pernyataan sistem bagi hasil mudharabah lebih menarik disbanding produk syariah lainnya, tidak ada responden $(0 \%)$ yang menyatakan sangat tidak setuju, 3 responden (10,0\%) menyatakan tidak setuju, 6 responden $(20,0 \%)$ menyatakan raguragu, 12 responden $(40,0 \%)$ menyatakan setuju, dan 9 responden $(30,0 \%)$ menyatakan sangat setuju.

e. Pada Keputusan Nasabah $(\mathrm{Y})$ mendapatkan respon sebgai berikut:

1) Dari pernyataan menjadi nasabah BMT Hidayah Umat merupakan dorongan syariah, tidak ada responden $(0 \%)$ yang menyatakan sangat tidak setuju, 4 responden $(13,3 \%)$ menyatakan tidak setuju, 5 responden $(16,7 \%)$ menyatakan raguragu, 13 responden $(43,3 \%)$ menyatakan setuju, dan 8 responden $(26,7 \%)$ menyatakan sangat setuju.

2) Dari pernyataan pelayanan yang diberikan karyawan/i sudah memberikan kepuasan kepada nasabah, tidak ada responden $(0 \%)$ yang menyatakan sangat tidak setuju, 6 responden $(20,0 \%)$ menyatakan tidak setuju, 7 responden $(23,3 \%)$ menyatakan raguragu, 13 responden $(43,3 \%)$ menyatakan setuju, dan 4 responden $(13,3 \%)$ menyatakan sangat setuju.

3) Dari pernyataan apabila produk yand ditawarkan memberikan kemudahan kepada anda, maka anda akan tetap menggunakan jasa BMT Syariah sebagai lembaga keuangan yang anda percaya, ada 1 responden $(3,3 \%)$ yang menyatakan sangat tidak setuju, 3 responden $(10,0 \%)$ menyatakan tidak setuju, 8 responden $(26,6 \%)$ menyatakan ragu-ragu, 14 responden $(46,7 \%)$ menyatakan setuju, dan 5 responden $(16,7 \%)$ menyatakan sangat setuju.

4) Dari pernyataan apabila anda puas dengan sistem dan pelayanan yang diberikan pihak BMT, tentu anda akan merekomendasikannya kepada pihak lain (keluarga, rekan, orang lain) tidak ada responden $(0 \%)$ yang menyatakan sangat tidak setuju, 1 responden $(3,3 \%)$ menyatakan tidak setuju, 6 responden $(20,0 \%)$ menyatakan ragu-ragu, 15 responden $(50,0 \%)$ menyatakan setuju, dan 8 responden $(16,7 \%)$ menyatakan sangat setuju.

5. Analisis Kuantitatif

Analisis regresi linier berganda diperoleh model persamaan $Y=$ $2,689+0,372 X_{1}+0,266 X_{2}+0,013 X_{3}+0,153 X_{4}+$ e. Pada uji parsial faktor syariah menyatakan hasil analisis ini dinyatakan signifikan karena thitung $<$ ttabel pada $a=5 \%$, dengan nilai $0.021<0.05$ sehingga hipotesis diterima. Artinya bahwa pengaruh faktor syariah terhadap keputusan nasabah adalah positif dan signifikan, sedangkan faktor pelayanan, produk, dan promosi dinyatakan tidak signifikan karena thitung $>$ ttabel pada $a=5 \%$, Artinya bahwa pengaruh faktor pelayanan, produk, dan promosi terhadap keputusan nasabah adalah positif dan tidak signifikan.

Murningsih 


\section{Uji statistik $F$}

ANOVA $^{\mathrm{b}}$

\begin{tabular}{|l|r|r|r|c|c|}
\hline Model & Sum of Squares & df & Mean Square & F & Sig. \\
\hline 1 Regression & 118.753 & 4 & 29.688 & 16.851 & $.000^{\mathrm{a}}$ \\
Residual & 44.047 & 25 & 1.762 & & \\
Total & 162.800 & 29 & & & \\
\hline
\end{tabular}

Hasil uji $\mathrm{F}$ untuk permintaan pembiayaan mudharabah sebesar 0,000. Hasil uji tersebut berada di bawah nilai alpha 0,05, kemudian nilai Fhitung sebesar 16,851 sedangkan nilai Ftabel sebesar 1,697 (Fhitung > Ftabel) sehingga dapat disimpulkan bahwa terdapat pengaruh signifikan secara simultan antara variabel independen (syarian, pelayanan, produk, dan promosi) terhadap permintaan pembiayaan mudharabah.

Tabel Model Summary

\begin{tabular}{|l|l|r|r|r|r|}
\hline Model & $\mathrm{R}$ & $\mathrm{R}$ Square & $\begin{array}{c}\text { Adjusted R } \\
\text { Square }\end{array}$ & $\begin{array}{c}\text { Std. Error of the } \\
\text { Estimate }\end{array}$ & $\begin{array}{c}\text { Durbin- } \\
\text { Watson }\end{array}$ \\
\hline 1 & $.854^{\mathrm{a}}$ & .729 & .686 & 1.327 & 1.687 \\
\hline
\end{tabular}

Dari hasil statistik diperoleh koefesien determinasi $\mathrm{R}^{2}=0,729$ yang berarti $72,9 \%$ dari variasi variabel terikat (dependen) dapat dijelaskan oleh variasi variabel bebasnya (independen), sedangkan $27,1 \%$ lainnya dijelaskan oleh variasi variabel lain di luar penelitian ini.

Uji normalitas hasil K-S, dengan nilai $\alpha=0,05$. Untuk loyalitas pembiayaan mudharabah (Y) memberikan nilai 0,915 dengan probabilitas 0,373 , untuk loyalitas syariah (X1) memberikan nilai 0,697 dengan probabilitas 0,717, untuk loyalitas pelayanan (X2) memberikan nilai 0,816 dengan probabilitas 0,518 , untuk loyalitas produk (X3) memberikan nilai 0,861 dengan probabilitas 0,449, untuk loyalitas promosi memberikan nilai 0,809 dengan probabilitas 0,530 , terlihat bahwa semua variabel independen mempunyai nilai Asymp. Sig. (2-Tailed) > 0,05, yang artinya bahwa data residual

Analisis Faktor berdistribusi normal.

Dari tabel uji Durbin Watson di atas menunjukkan bahwa nilai Durbin-Watson sebesar 1,687, dengan nilai signifikansi 0,05 dan $\mathrm{k}=$ 4, maka akan diperoleh nilai du sebesar 1,74 dan dl sebesar 1,14. karena nilai $\mathrm{du}<\mathrm{d}<4$-du, 1,74 $<1,687<2,26$, maka dapat disimpulkan bahwa pada model regresi tidak terdapat gejala autokorelasi baik secara positif maupun negatif. 
Dari uji multikolinieritas Dari uji multikolinieritas nilai loyalitas syariah memiliki nilai Tolerance 0,480 dan VIF 2,082, loyalitas pelayanan memiliki nilai Tolerance 0,291 dan VIF 3,442, loyalitas produk memiliki nilai Tolerance 0,137 dan VIF 7,286, dan loyalitas promosi memiliki nilai Tolerance 0,139 dan VIF 7,205. Maka dapat disimpulkan bahwa pada model regresi tidak terdapat gejala multikolinieritas.

\section{G. Kesimpulan}

Berdasarkan pada analisis yang telah dilakukan terhadap data hasil penelitian, maka dapat diambil kesimpulan sebagai berikut:

1. Hasil pengujian secara parsial

a. Faktor syariah secara statistik berpengaruh positif dan signifikan terhadap permintaan pembiayaan mudharabah, hal ini dapat dilihat dari koefisien regresi sebesar 0,372 dan nilai signifikansi sebesar 0,021 dengan nilai $a=5 \%$. Dari hasil uji tersebut dapat disimpulkan bahwa faktor syariah berpengaruh positif dan signifikan terhadap permintaan pembiayaan mudharabah.

b. Faktor pelayanan secara statistik berpengaruh positif dan tidak signifikan terhadap permintaan pembiayaan mudharabah, hal ini dapat dilihat dari koefisien regresi sebesar 0,266 dan nilai signifikansi sebesar 0,068 dengan nilai $\alpha=5 \%$.

c. Faktor produk secara statistik berpengaruh positif dan tidak signifikan terhadap permintaan pembiayaan mudharabah, hal ini dapat dilihat dari koefisien regresi sebesar 0,013 dan nilai signifikansi sebesar 0,958 dengan nilai $\alpha=5 \%$.

d. Faktor promosi secara statistik berpengaruh positif dan tidak signifikan terhadap permintaan pembiayaan mudharabah, hal ini dapat dilihat dari koefisien regresi sebesar 0,153 dan nilai signifikansi sebesar 0,496 dengan nilai $a=5 \%$.

2. Nilai $R$ Square $\left(R^{2}\right)$ adalah sebesar 0,729 hal ini berarti permintaan pembiayaan mudharabah cukup mampu dijelaskan oleh variabel independen yaitu syariah, pelayanan, produk, dan promosi sebesar 72,9 $\%$ dan sisanya dijelaskan oleh variabel lain di luar penelitian ini, misalnya variabel bagi hasil, suku bunga, pendapatan dan sebagainya. 


\section{DAFTAR PUSTAKA}

Achmad Baraba, 2007. Prinsip Dasar Operasional Perbankan Syariah, Majalah Buletin Ekonomi, Bank Indonesia Jakarta.

Arikunto. Suharsimi, 2002. Prosedur Penelitian suatu Pendekatan Praktik, Jakarta: Rineka Cipta.

Basu Swastha, 2008. Manajemen Pemasaran Modern, Edisi Kedua, Yogyakarta: Liberty.

Buchari Alma, 2006. Manajemen Pemasaran dan Pemasaran Jasa, Bandung: Alfabeta.

Didin Hafidhuddin, 2001. Pelatihan Perbankan Syariah, Tazkia Institute, dalam M. Syafii Antonio. Bank Syariah dari Teori ke Praktek, Gema Insani : Jakarta).

Hendrojogi, 2000. Koperasi, Asas-asas, Teori Dan Praktik, Edisi Revisi. Jakarta: Fajar Pratama Offset.

Imam Ghazali, 2005. Analisis Multivariate dengan program SPSS. Semarang: Badan Penerbit Universitas Diponegoro.

Kasmir, 2005. Pemasaran Bank, Cet 2, Jakarta: PT Raja Grafindo Persada.

Kasmir, 2003. Manajemen Perbankan, Cet ke IV. Jakarata: Raja Grafindo Persada.

M. Amin Aziz, 2005. Mengembangkan Bank Islam di Indonesia, Jakarta: CV Rajawali.

Muhamad, 2000. Lembaga Keuangan Umat Kontemporer, Yogyakarta: UII Press.

Muhamad, 2002. Manajemen Bank Syari'ah, cet. 1. Yogyakarta: UPP AMP YKPN.

Muhamad, 2009. Model-model Akad Pembiayaan Di Bank Syariah, Yogyakarta: UII Press.

Muhammad Ridwan, 2004. Manajemen BMT, Yogyakarta: UII Press.

Muhammad Syafi'I Antonio, 2001. Bank Syariah Dari Teori ke Praktik. Jakarta: Gema Insani.

Muhammad, 2000. Lembaga-lembag Keuangan Umat Kontemporer, cet, 1. Yogyakarta: UII Press.

Analisis

Faktor
Muhammad, 2006. "Permasalahan Agency Dalam Pembiayaan
Mudharabah Pada Bank Syariah di Indonesia", disertai Pasca Sarjana MSI UII Yogyakarta.

Riduwan dan Sunarto, 2009. Pengantar Statistika Untuk Penelitian Pendidikan, Social, Ekonomi, Komunikasi, dan Bisnis, Yang dilengkapi dengan aplikasi SPSS, Bandung: Alfabeta.

Supardi, 2005. Metodologi Penelitian Ekonomi dan Bisnis, Yogyakarta: UII Press. 
Sutrisno Hadi, 1996. Metode Research, (Yogyakarta: Yayasan Penerbit Fakultas Psikologi UGM).

Umar Husein, 2005. Metodologi Penelitian Untuk Skripsi Dan Tesis Bisnis, Jakarta: PT Rajagrafindo Persada.

Murningsih 